\title{
AN ATTEMPT TO APPLY TREND-SURFACE ANALYSIS TO THE STUDY OF RAISED SHORELINES OF THE BALTIC SEA IN ESTONIA
}

\author{
Avo MIIDEL
}

Eesti Teaduste Akadeemia Geoloogia Instituut (Institute of Geology, Estonian Academy of Sciences), Estonia pst. 7, EE-0100 Tallinn, Eesti (Estonia)

Received 28 June 1994, accepted 20 October 1994

Abstract. Transgressive shorelines of the Baltic Ice Lake, Ancylus Lake, and Litorina Sea were studied by trend-surface analysis.

A linear trend surface refers to a regular uplift. Second and cubic degree surfaces reveal curved isobases, probably arising from glacioisostatic movements of Fennoscandia, but not from the bedrock geology and tectonics in Estonia.

According to the findings of an analysis of residuals, it appeared impossible to connect convincingly residuals of less than $2 \mathrm{~m}$, prevailing in Estonia, with local tectonic movements. Consequently, the role of these movements was very slight in the development of the topography in the Late Glacial and Holocene.

Key words: shorelines, Baltic Ice Lake, Ancylus Lake, Litorina Sea, trend analysis, raised areas, subsiding areas, local tectonic movements and structures, glacioisostatic uplift.

\section{INTRODUCTION}

Trend-surface analysis has been successfully applied to the study of topography and raised shorelines by several authors (Saarnisto \& Huhn, 1972; Gray, 1974, 1978; Heikkinen, 1975; Heikkinen \& Kurimo, 1977). Taking into consideration the wide distribution and good preservation of ancient beach ridges in Estonia, it is of interest to employ the method in the analysis of shorelines of the Baltic Sea here, too.

The present study was started together with late Helgi Kessel, who presented all the necessary initial data. Unfortunately, it did not prove possible to complete this work together.

Basing on trend-surface analysis, the present study is aimed at getting an answer to two questions:

(1) Are the isobases of the uplift determined by raised shorelines of the Baltic Sea indeed straight lines as shown in numerous papers hitherto? The only exceptions are the study by Ramsay (1929) and the Neotectonic Map of the Soviet Baltic Republics (Шляупа et al., 1982) on which isobases are presented as curved lines.

(2) Was the uplift regular over the whole territory or were there also irregularities, caused by block-wise movements and faultings as it has been supposed (Хейнсалу \& Сильдвээ, 1971; Ряхни, 1973; Шляупа et al., 1982)? 
Coastal formations of the transgressions of the Baltic Ice Lake, Ancylus Lake, and Litorina Sea were studied. Data on the coastal forms (coastal scarps, beach ridges, spits, etc.) of the Baltic Ice Lake (phase B III) were derived from 61 sites. The heights of 57 points were levelled and the heights of 4 points were obtained from a large-scale topographic map. In nature the altitudes of coastal forms were measured with an accuracy of $\pm 0.5 \mathrm{~m}$, but for altitudes determined on maps the error may exceed $2 \mathrm{~m}$. The absolute height of the shore formations decreases from $68.0 \mathrm{~m}$ in the northwest to $30.0 \mathrm{~m}$ in the southeast.

From the raised beaches of the Ancylus Lake (A I) 66 sites were used, among which 53 were levelled and the heights of the rest were obtained from maps. Their height is likewise the greatest in the northwest $(44.8 \mathrm{~m}$ at Kõpu, Hiiumaa Island) and the smallest in southeastern Estonia ( $4.0 \mathrm{~m}$ at Lemmeoja).

In studying the raised beaches of the Litorina Sea 77 observation points were used. Among these 63 were levelled. The altitudes of the rest were found from maps. The coastal forms on the Kõpu Peninsula lie at a height of $27.9 \mathrm{~m}$, but in southeastern Estonia (at Ikla) their height is only $4.0 \mathrm{~m}$. Because of the rather long duration of the Litorina transgression its maximum level is not synchronous (Кессел \& Раукас, 1984).

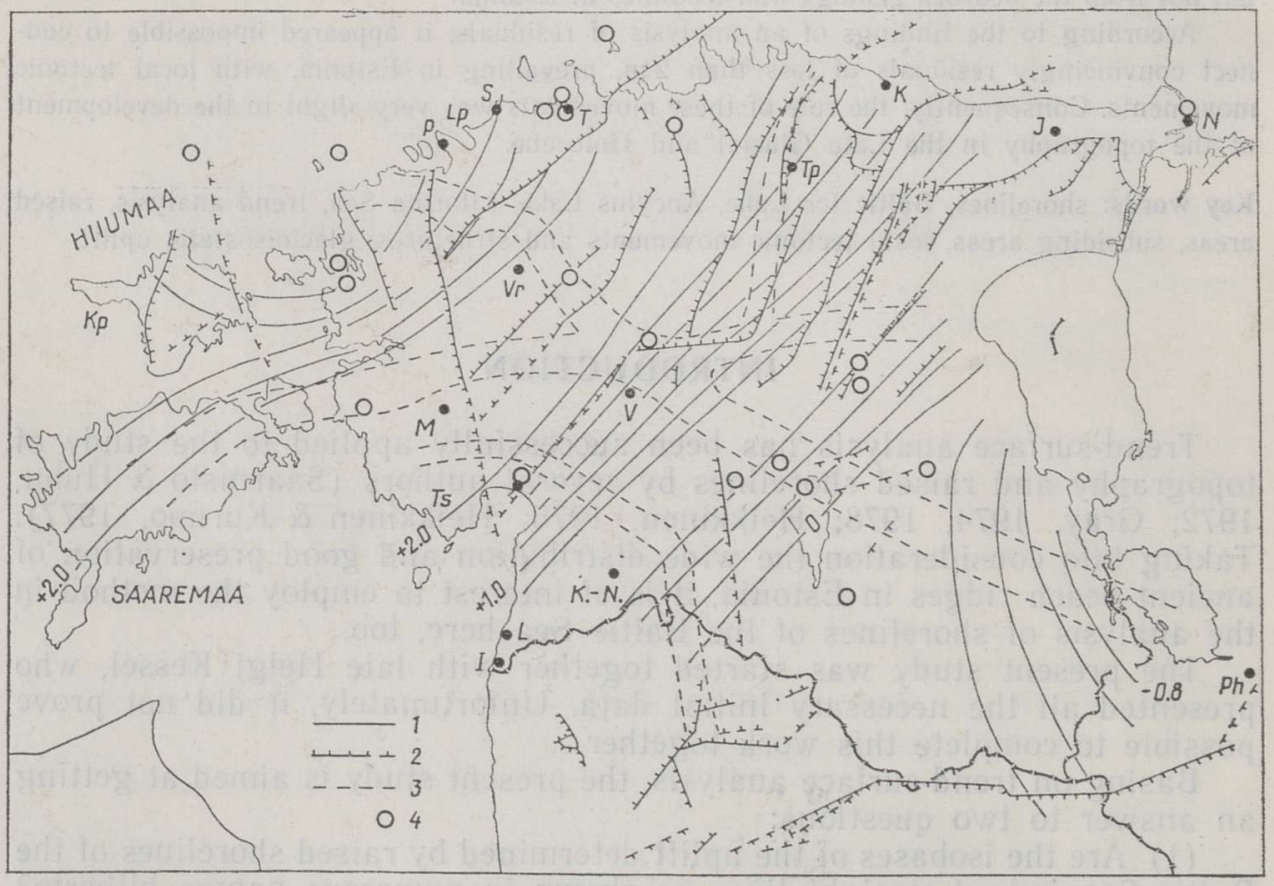

Fig. 1. Main features of the tectonics: 1 isobases of recent movements, mm/year (after Vallner et al., 1988); 2 platform faults and flexures (after Вахер, 1983; Туулинг, 1990); 3 deep-seated fault zones in the basement (after Побул \& Сильдвээ, 1975); 4 epicentres of earthquakes (after Sildvee, 1991).

Sites: I, Ikla; J, Jõhvi; K, Kunda; Kp, Kõpu Peninsula; K.-N., Kilingi-Nõmme; L, Lemmeoja; Lp, Lohusalu Peninsula; M, Mihkli; N, Narva; P, Paldiski; Ph, Pihkva; Pr, Pärnu; S, Suurupi; T, Tallinn; Tp, Tapa; Ts, Tõstạmạa Penninsula; V, Vạnndra; Vr, Vạrbola, 
The computation of the trend surfaces was carried out with the aid of the programs STATEC-4 (Тийтс et al., 1986) and XXGRAF (Оргла, 1991) by Kalev Orgla. For analysis only linear, quadratic, and cubic trend surfaces were used. The data obtained were compared with the geology (Fig. 1).

\section{ISOBASE MAPS AND THEIR INTERPRETATION}

The linear surface of the Baltic Ice Lake is a plane, evenly tilted from the northwest to the southeast (Fig. 2). The azimuth of rectilinear isobases, running from the northeast to the southwest, is $53^{\circ}\left(233^{\circ}\right)$ and the maximal gradient runs accordingly in a direction $143^{\circ}$.

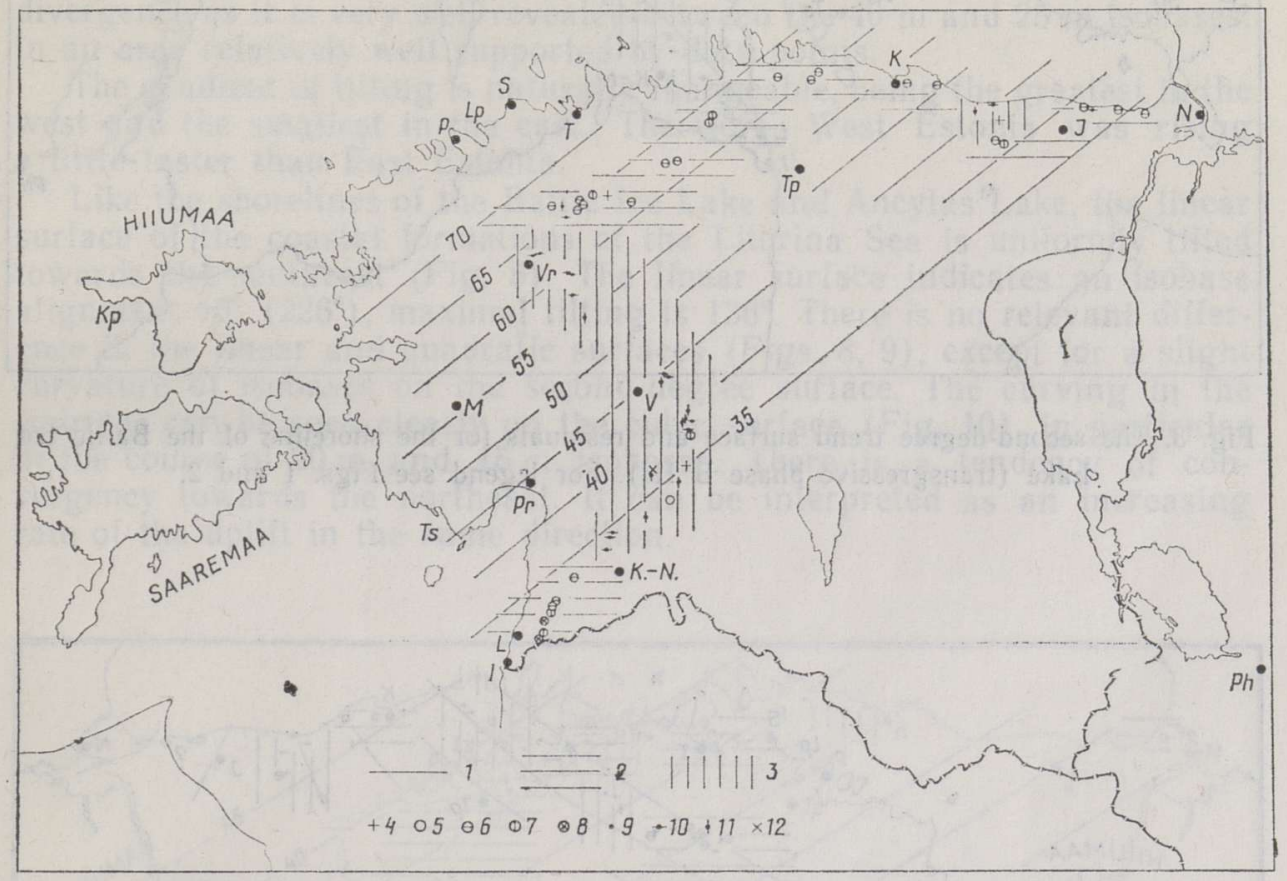

Fig. 2. The first-degree trend surface and residuals for the shoreline of the Baltic Ice Lake (transgressive phase B III). 1 isobases; 2 area with positive residuals (relatively raised area); 3 area with negative residuals (relatively subsided area); values of residuals (metres) : $4=0 ; 5$ from 0.1 to $1.0 ; 6$ from 1.1 to $2.0 ; 7$ from 2.1 to $4.0 ; 8 \geqslant 4.1 ; 9$ from -0.1 to $-1.0 ; 10$ from -1.1 to $-2.0 ; 11$ from -2.1 to $-4.0 ; 12 \geqslant-4.1$.

The quadratic and cubic trend surfaces differ considerably from the linear surface (Figs. 3,4). The quadratic surface is notably concave because the distance between isobases increases towards the southeast due to changes in the gradient of tilting. The same can be said about the cubic surface. In addition to being curved the isobases of the cubic surface spread out in a fan shape towards the northeast. Attention is attracted by an area of relative subsidence contoured by the $35 \mathrm{~m}$ isobase in southeastern Estonia and a strange behaviour of isobases in the northeasternmost part of the territory. The latter may be caused by the uneven distribution of the observation points in the studied area. The cubic trend surface could be caused by faster emergence of West Estonia up to the Pärnu River as compared to the North-Estonian coastal area. 


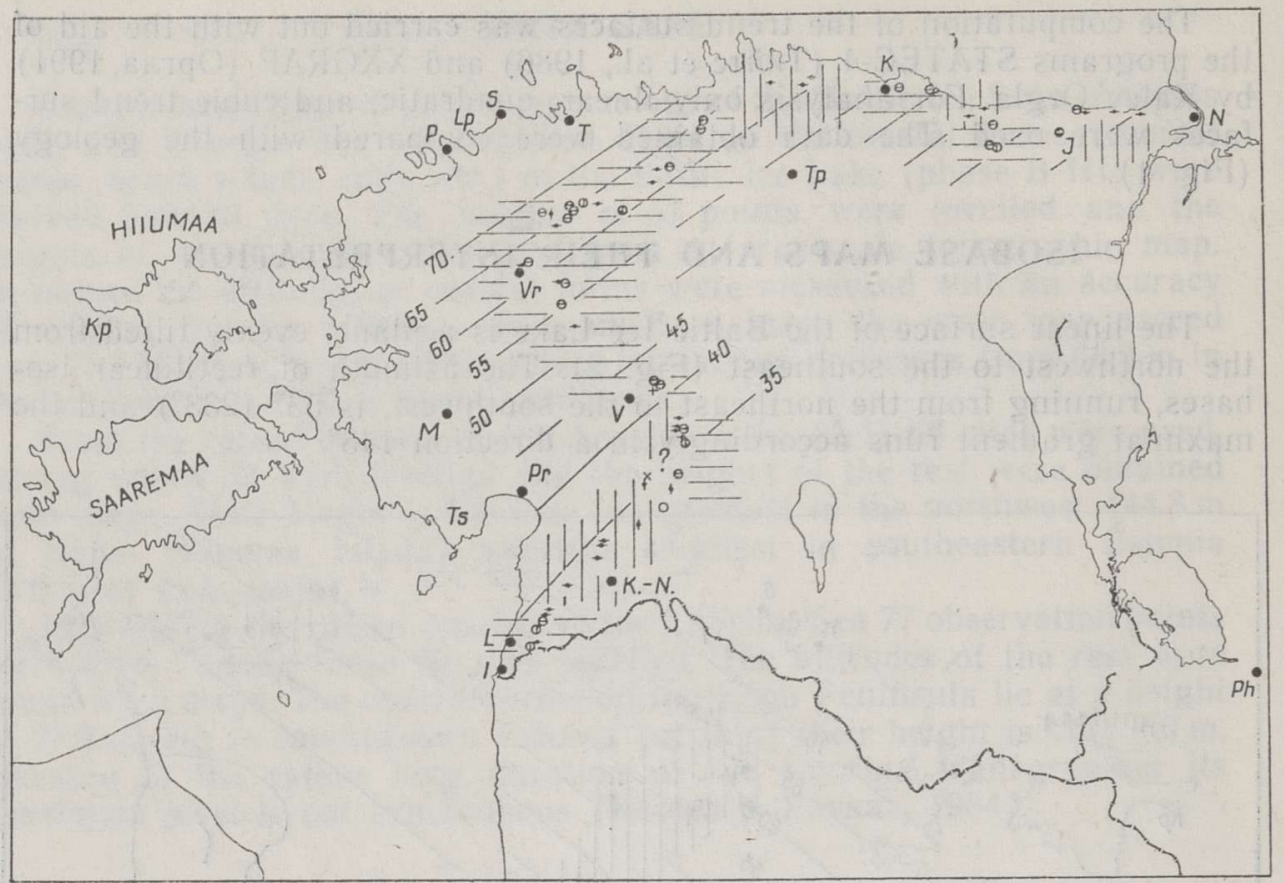

Fig. 3. The second-degree trend surface and residuals for the shoreline of the Baltic Ice Lake (transgressive phase B III). For legend see Figs. 1 and 2.

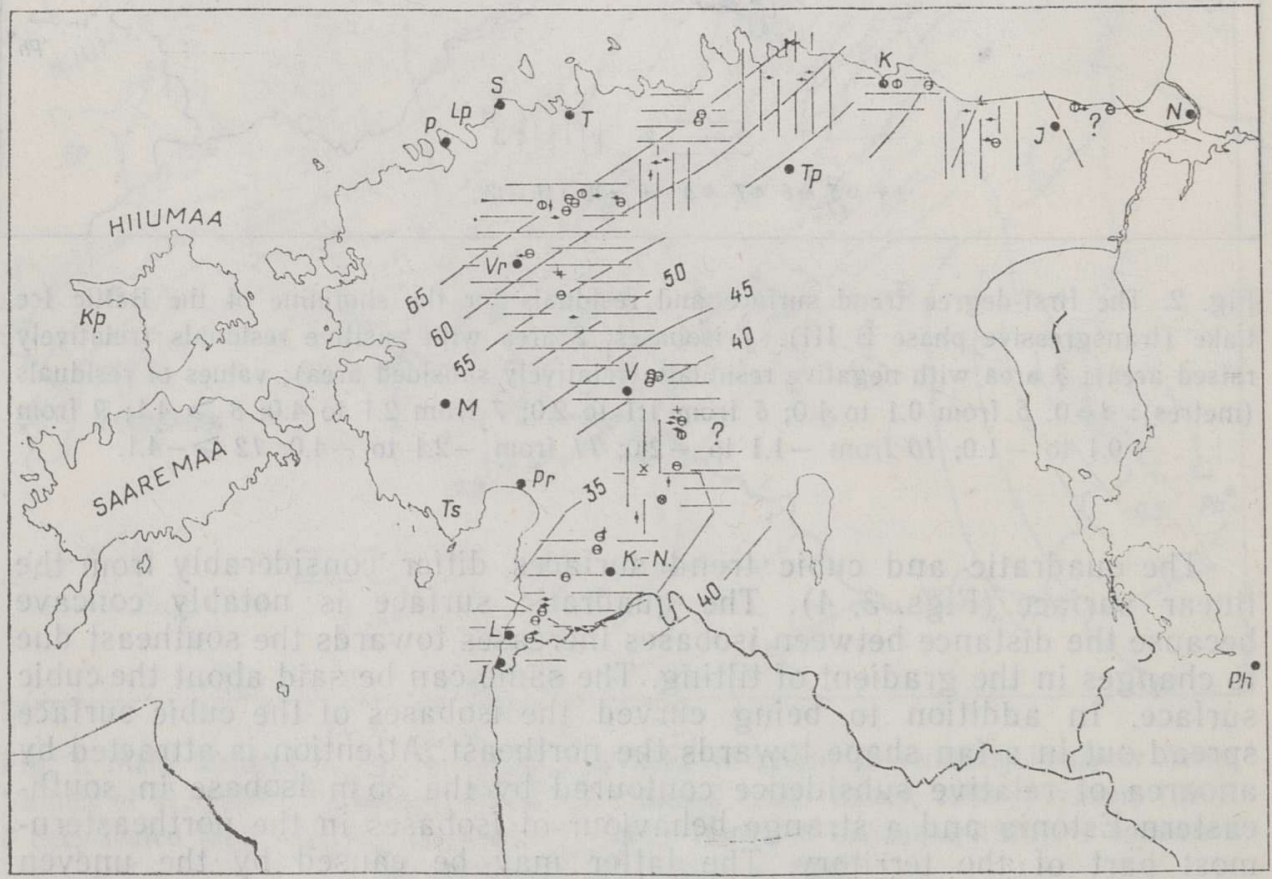

Fig. 4. The third-degree trend surface and residuals for the shoreline of the Baltic Ice Lake (transgressive phase B III). For legend see Figs. 1 and 2. 
The subsidence area in southwestern Estonia is bounded from all sides, except for the southeast, by gravity gradient zones. At the same time this area is situated between two gradient zones of the contemporary movements (Fig. 1). Consequently, the local subsidence seems to be supported by geological data.

The linear surface of the coastal formations of the Ancylus Lake also has a regular tilt towards the southeast (Fig. 5), but the rectilinear isobase alignment has changed to some extent being now $48^{\circ}\left(228^{\circ}\right)$. The azimuth of the direction of uplift is thus $138^{\circ}$. The quadratic surface (Fig. 6) is very similar to that of the linear one except for a slight oblique course of isobases. Such a course can be seen distinctly on the cubic surface where the divergence of isobases towards the northeast is very obvious (Fig. 7). There seems to be no doubt in the northeastward divergence as it is very well revealed between the $40 \mathrm{~m}$ and $25 \mathrm{~m}$ isobases, in an area relatively well supported by data points.

The gradient of tilting is naturally changeable, being the greatest in the west and the smallest in the east. Therefore, West Estonia was rising a little faster than East Estonia.

Like the shorelines of the Baltic Ice Lake and Ancylus Lake, the linear surface of the coastal formations of the Litorina Sea is uniformly tilted towards the southeast (Fig. 8). The linear surface indicates an isobase alignment $46^{\circ}\left(226^{\circ}\right)$, maximal tilting is $136^{\circ}$. There is no relevant difference in the linear and quadratic surfaces (Figs. 8, 9), except for a slight curvature of isobases on the second-degree surface. The curving in the isobases can be seen clearly on the cubic surface (Fig. 10), in particular in the course of $20 \mathrm{~m}$ and $15 \mathrm{~m}$ isobases. There is a tendency of convergency towards the northeast. It can be interpreted as an increasing rate of the uplift in the same direction.

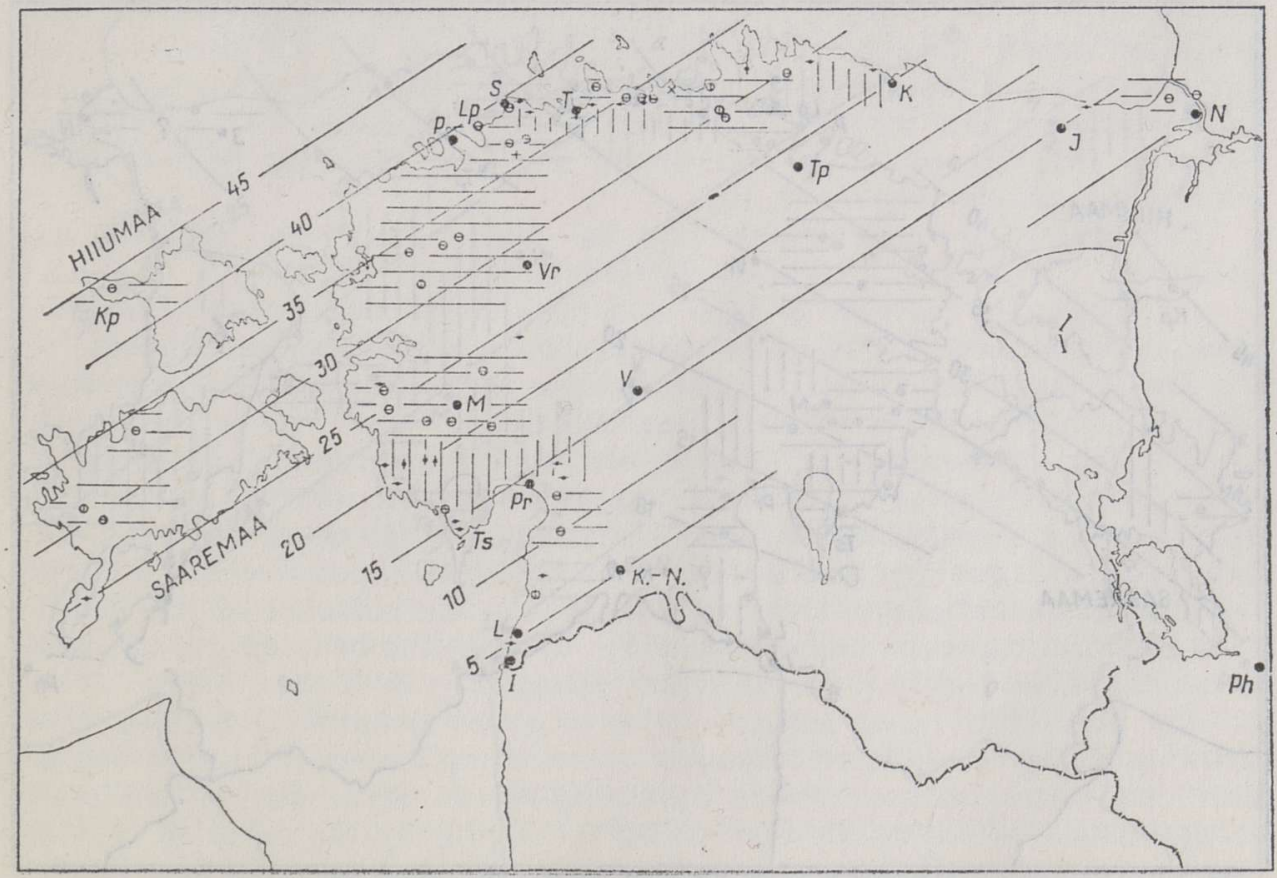

Fig. 5. The first-degree trend surface and residuals for the transgressive shoreline of the Ancylus Lake. For legend see Figs. 1 and 2. 


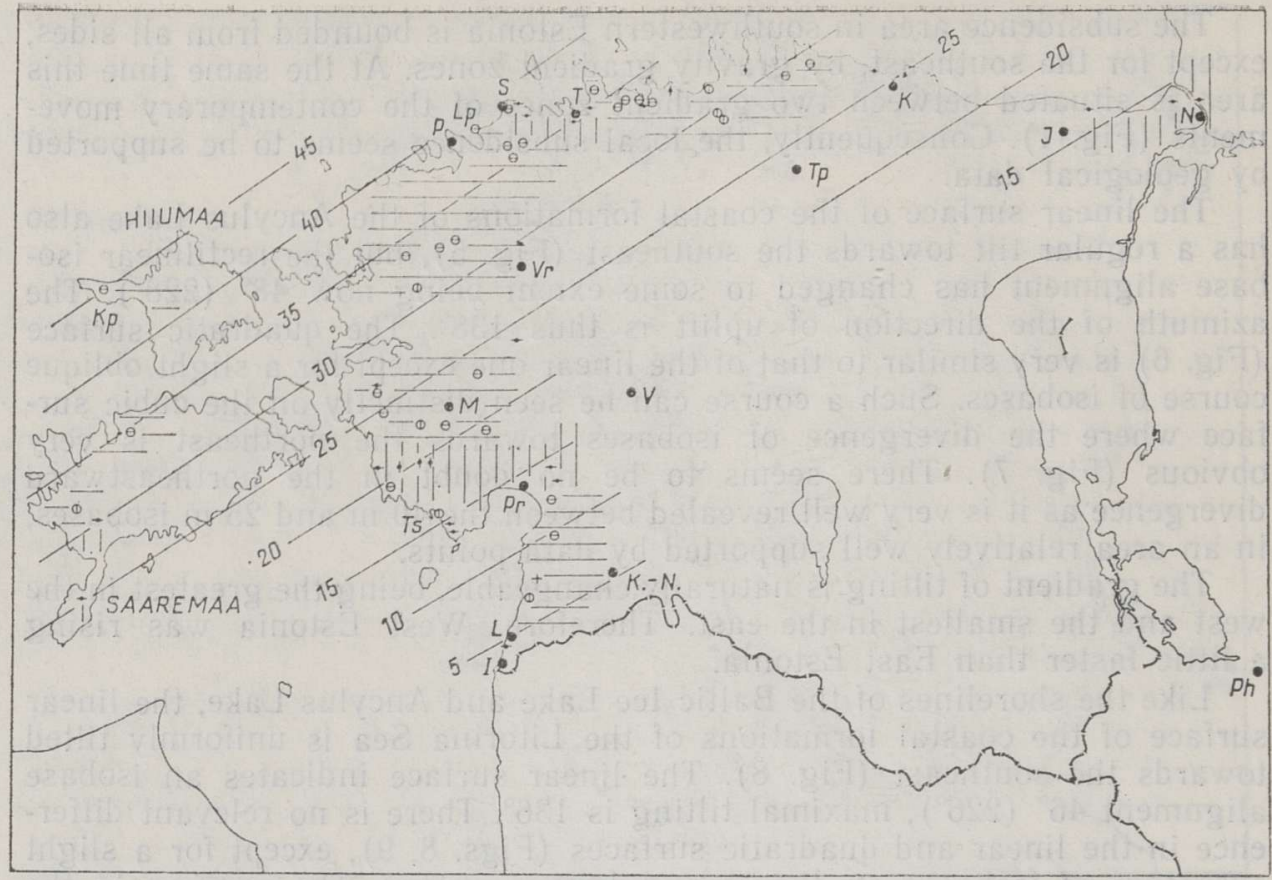

Fig. 6. The second-degree trend surface and residuals for the transgressive shoreline of the Ancylus Lake. For legend see Figs. 1 and 2.

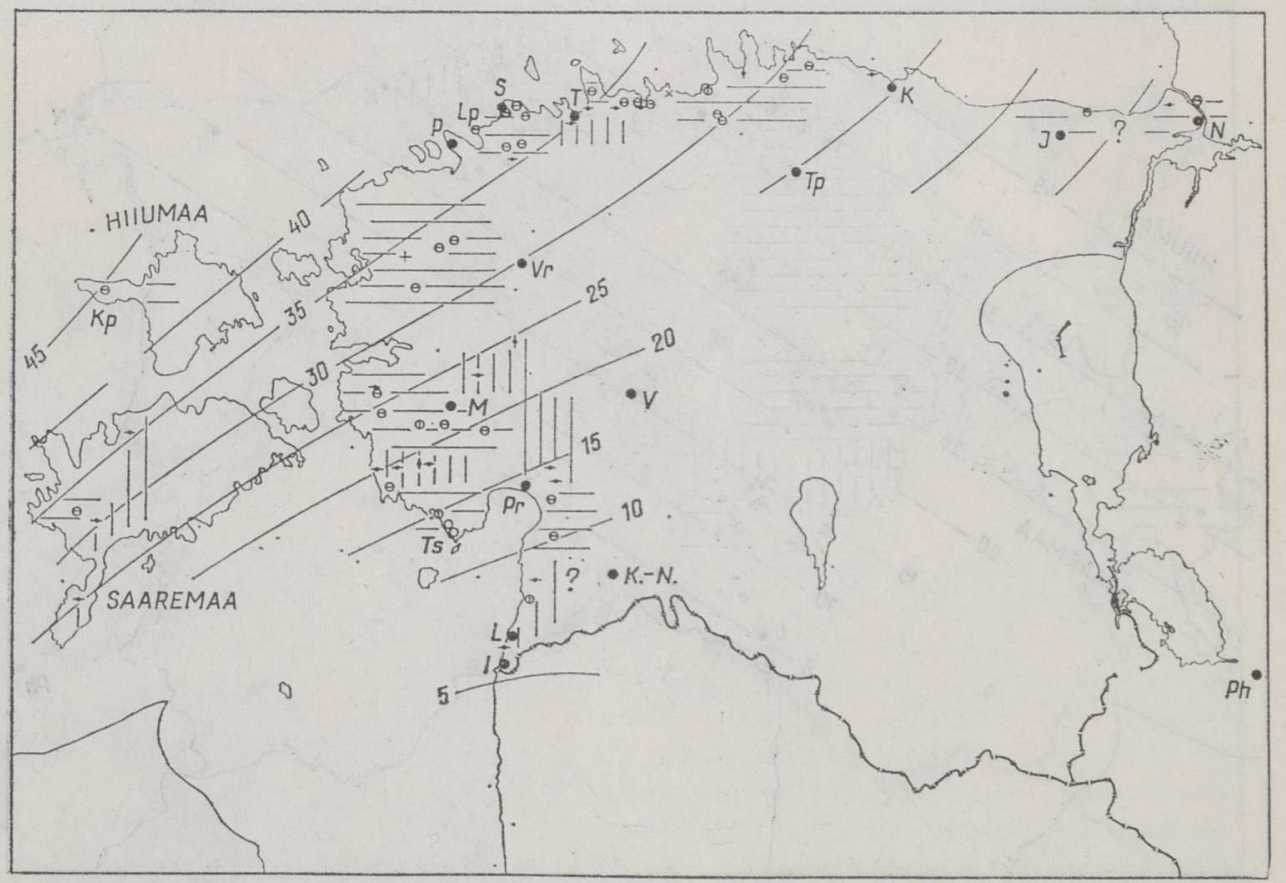

Fig. 7. The third-degree trend surface and residuals for the transgressive shoreline of the Ancylus Lake, For legend see Figs. 1 and 2. 


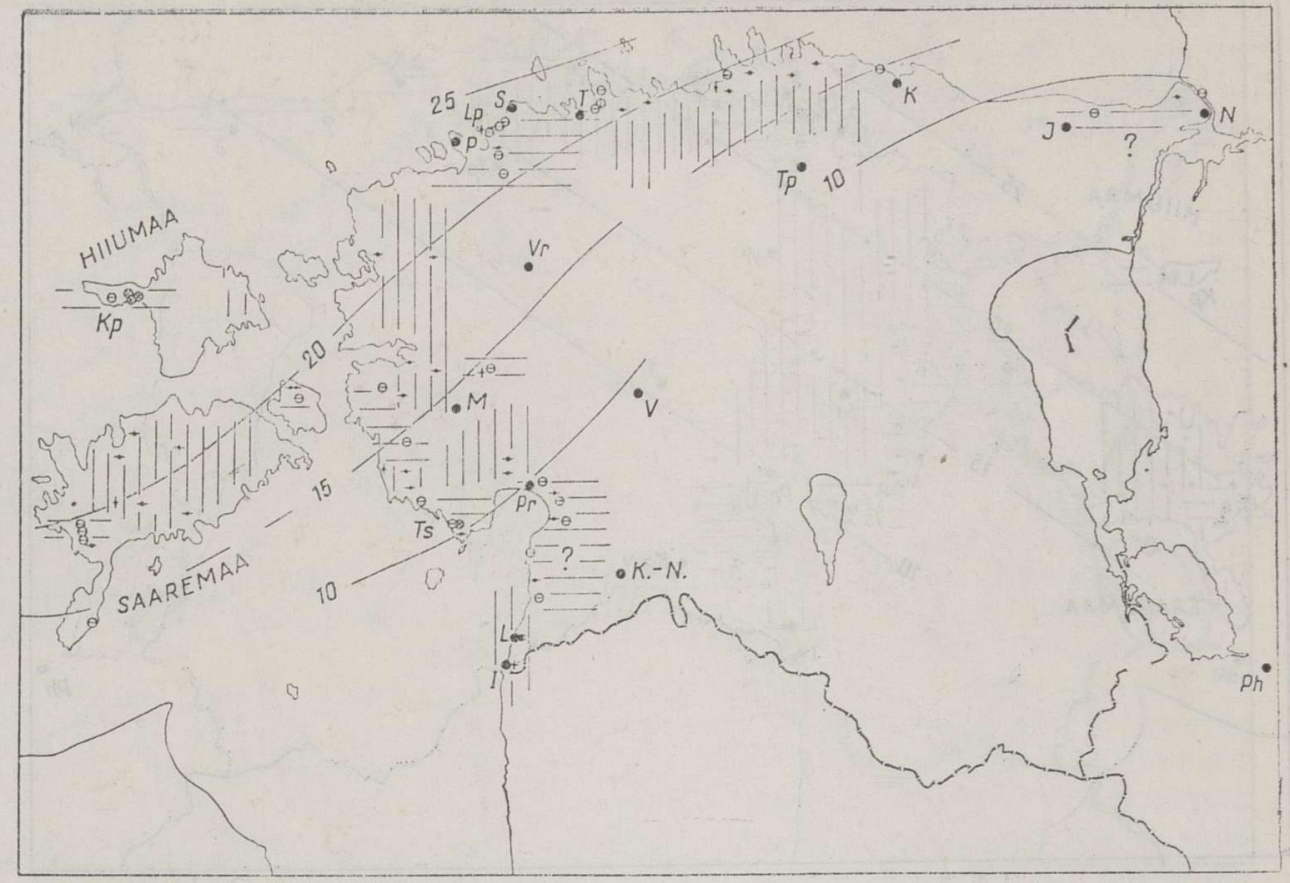

Fig. 10. The third-degree trend surface and residuals for the transgressive shoreline of the Litorina Sea. For legend see Figs. 1 and 2.

A comparison of trend surfaces of the same degree but different age reveals their great similarity. All linear surfaces, regardless of their age, are tilted evenly towards the southeast (Figs. 2, 5, 8). An undetermined oblique course of isobases can be seen on the second-degree surfaces. The cubic surfaces are already characterized by a considerable curving in isobases that increases in accordance with the decrease in the age of coastal formations (Figs. 4, 7, 10).

The following conclusions can be drawn from the trend-surface analysis:

(1) The main features of late- and postglacial movements have been once again confirmed. The trend surfaces show that the extent and rate of the uplift decrease from the northwest to the southeast. The same data also indicate that the uplift decreases with time.

(2) The above-presented data do not prove the block-wise character of late- and postglacial movements suggested earlier (Ряхни, 1973). For example, the declared dome-like Pandivere high (Шляупа et al., 1982) cannot be seen on the trend surfaces describing the spatial distribution of the coastal formations of the Baltic Ice Lake. The presence of the Pandivere high has not been supported by the data on the bedrock geology and tectonics of the Baltic Ice Lake either (Карукяпп \& Таваст, 1985).

(3) The linear trend surfaces refer to an even uplift in Estonia. The calm and regular picture becomes more complicated in higher-degree surfaces, where isobases obtain a curving form, maybe due to territorial irregularities in the uplift. For example, judging by the cubic surface of the transgressive shoreline of the Ancylus Lake it is possible that Saaremaa Island and West Estonia have risen faster than the northeastern area where the isobases are diverging (Fig. 7). Later the tendency reversed itself. The attempts to find causal connections between the curving of the 
isobases and the bedrock geology and tectonics failed. If the established territorial differences in the movements of the Earth's crust are real indeed then these variations should be treated as resulting from glacioisostatic movements of Fennoscandia. However, our data indicate that in general the isobases could be regarded as straight lines. Their curvings become visible in detailed studies only. They may be lost on small-scaled maps, often drawn by hand. This could be the answer to the first question presented at the beginning of the paper, namely whether the isobases of the uplift are really straight lines.

(4) As is generally known, a hinge-line has been determined across the Pärnu-Navesti-Narva line on the ground of changes in the gradient of shorelines of the Baltic Ice Lake (Пярна, 1962). Its position coincides with dislocations in the basement and sedimentary cover. Geodetic and geomorphologic data show that this old zone of weakness came active again in the Late Glacial and has been moving up to the present (Орвику, 1960, 1969; Уттер, 1964; Zhelnin, 1966; Мийдел, 1966; Кессел \& Мийдел, 1973). In a way the hinge-line can be seen in the third-degree surface of the shoreline of the Baltic Ice Lake (Fig. 4), yet the results about younger shorelines do not give an unambiguous answer.

(5) It was established already long ago that the maximal direction of tilting had changed from $155^{\circ}$ (local ice-dammed lakes), $146^{\circ}$ (the Baltic Ice Lake, Ancylus Lake, and Litorina Sea), $135^{\circ}$ (the Limnea Sea) up to $130-135^{\circ}$ (today) (Пярна, 1962; Кессел \& Мийдел, 1973). The present study confirms the tendency to some extent. It is possible that changes in the direction of tilting could be connected with the shifting of the Fennoscandian uplift centre westwards during the Late Glacial. The migration of the uplift centre was supposed earlier by several authors (Lundqvist, 1965; Mörner, 1969; Кошечкин, 1984). The regular change in the direction of tilting may also imply that the role of the glacioisostatic factor in the total uplift has been gradually diminishing since the Late Glacial towards the present. Fluctuations in the direction of tilting were studied by Løken (1962) in Labrador. He found that deviations of $5^{\circ}$ in the average direction of isobases had no significance. Though in the present case the total difference is at least $20^{\circ}$, the problem evidently requires more thorough investigation.

\section{RESIDUALS AND THEIR INTERPRETATION}

Since no local tectonic movements have been discovered in trend surfaces, it was decided to use residuals, i. e. the differences between the measured heights of shore formations and those calculated from the trend surfaces. According to Heikkinen (1975) residuals may reveal local factors that would otherwise remain hidden in a regional treatment. Studying the topography in Sipoo, southern Finland, he found a connection between the pattern of residuals and bedrock geology and tectonics.

In the present study the existence of a certain pattern in the distribution of residuals was assumed. This enabled to distinguish areas with either mainly positive or negative residuals. One has to admit that the procedure is rather disputable, because heights and residuals of coastal formations, situated almost side by side, differ often notably, residuals having sometimes even an opposite sign. Reasons of these contradictions would certainly need separate analysis. In some cases discrepancies are probably caused by the different genesis of coastal formations, hydrodynamic conditions, exposure to and duration of prevailing wave action, lithology, etc. A very important reason may be the uneven distribution of coastal formations. Therefore, a large part of Central Estonia is "terra 
incognita". The irregular arrangement of observation points mày have diminished the efficiency of the applied trend-surface techniques in the present study. Nevertheless, the areas with positive and negative residuals were conditionally treated as relatively raised and subsided areas in lateand postglacial time. Their distribution was compared with geological data (Fig. 1).

Below residuals are dealt with beginning from the shoreline of the Baltic Ice Lake. The residuals. from the linear trend surface range from +5.9 to $-6.8 \mathrm{~m}$, with residuals from +1.1 to $-2.0 \mathrm{~m}$ prevailing $(60 \%)$. It should be pointed out that residuals with values from +1.1 to $-2.0 \mathrm{~m}$ prevail in all cases. Their share among the third-degree surfaces of the Ancylus Lake and Litorina Sea is up to $81-82 \%$. The percentage of the residuals exceeding $\pm 4 \mathrm{~m}$ is very modest $(2-7 \%)$.

In North Estonia there is a large area where coastal formations are somewhat higher from the linear trend surface (Fig. 2), being thus relatively more raised. A large area between Varbola and Kilingi-Nõmme is, on the contrary, lower, being thus relatively subsided or, in other words, this area rose less rapidly. Another emerged area is in southwestern Estonia, adjacent to the Latvian border. The southeastern part of the subsided area may be connected with the late-glacial hinge-line as this area is located within a hinge-line zone where the rate of recent movements has been rapidly changing (Fig. 1). Some low points occur in the Paldiski -Pihkva deep-seated fault zone. In northwestern Estonia there are some raised points in a gradient zone of contemporary movements. In spite of the above-mentioned coincidences we are not convinced that these deviations from the trend surface have been caused precisely by mobile dislocations in the bedrock or peculiarities of recent movements.

Quadratic and cubic residuals reveal greater differences in the studied territory (Figs. 3, 4). Values of the residuals get somewhat smaller (from +5.7 to $-4.6 \mathrm{~m}$ ). In northeastern Estonia there is an area with a vague tendency, where residuals with opposite signs occur side by side. A subsided area in the vicinity of Purtse is located in the Jöhvi basement block. A raised area at Kunda, adjacent to the former in the west, is situated in a block bounded by faults in the basement. In the territory of Lahemaa National Park one can see a lowered area at the border of the Tapa block and a gradient zone of recent movements. In the west there is a raised area that seems to be simultaneously connected with the Paldiski -Pihkva deep fault zone and gradients of the contemporary movements. To the south and southeast from Vändra two areas lying higher from their surroundings can be distinguished. They both may have been affected by recent movements.

The linear residuals of the coastal formations of the Ancylus Lake have values from +4.0 to $-4.3 \mathrm{~m}$. As already mentioned, residuals from +1.1 to $-2.0 \mathrm{~m}$ are predominant. Because of scanty data it is impossible to say anything definite about local movements in northeastern Estonia. The northwestern part of the studied territory, including islands, lies above the trend surface (Fig. 5). However, a small area between Tallinn and Suurupi is still characterized by negative residuals and a relatively high seismicity (Fig. 1). The raised northwestern Estonia seems to be separated from a subsided area situated approximately around Pärnu Bay by an arc-shaped deep-seated fault, bounding the bay and south-western Estonia from the north (Figs. 1,5).

The pattern of the third-degree residuals does not reveal any significant change in the areal distribution of subsided and raised areas. The only new moment is observable on Saaremaa Island, where the uplift shows a tendency to decelerate (Fig. 7).

The first-degree residuals of the coastal formations of the Litorina Sea 
range from $+3.8 \mathrm{~m}$ to $-4.4 \mathrm{~m}$. A large part of northeastern and northern Estonia (to the west from Lahemaa) and also Saaremaa Island (Fig. 8) seem to be lowered in relation to the trend surface, i. e. the rise was relatively slow. There are some raised areas as well (the coast between Tallinn and the Lohusalu Peninsula and the Kõpu Peninsula on Hiiumaa Island). At the same time, some areas (the eastern coast of Pärnu Bay) do not reveal any distinct tendency.

A comparison of data shows that finding whatever connection between deviations from the trend surfaces on the one hand and tectonics and recent movements of the Earth's crust on the other hand is very problematic. The same is valid to the scheme based on the cubic residuals. One can see that the number of blocks, lying at various heights, has increased (Fig. 10). In the vicinity of Tallinn a raised area seems to be located in a block bounded by submeridional and northeastern faults. To the west from the raised block there is a subsided one. The relatively high Kõpu Peninsula is separated from the rest of Hiiumaa Island by a meridional fault.

As the Baltic Ice Lake and later water basins do not coincide, it is impossible to trace the further movements of supposable blocks, determined by an analysis of the residuals of the Baltic Ice Lake shoreline. However, this kind of study yields certain results in case of the Ancylus Lake and Litorina Sea shorelines. It becomes apparent that the areas that had risen during the Ancylus Lake (Northwest and West Estonia, including Saaremaa Island) were subject to relative sinking in the Litorina Sea time (Figs. 7, 10).

\section{FINAL REMARKS}

The presented data show that even an analysis of residuals does not prove convincingly the existence of active young local structures and fault movements or mobile old fault zones at the end of the last glaciation and in the Holocene. This conclusion is not surprising. Svendsen and Mangerud (1987) are of the opinion that vertical faults could be seen in the shoreline diagram if the dislocation was more than $10 \mathrm{~m}$. Dislocations less than $4-5 \mathrm{~m}$ could easily be hidden. Therefore, to connect residuals less than $2 \mathrm{~m}$, prevailing in Estonia, with local tectonic movements would be very problematic. Even the largest values of residuals $(5-7 \mathrm{~m})$ cannot be regarded as evidences of tectonic movements. However, it should be mentioned that the general geological background for establishing local tectonic movements with small amplitudes is still inadequate.

Regardless of the uneven distribution of observation points and possible methodological deficiency, resulting from the former, the presented data seem to confirm the opinion that the role of local tectonic movements was very slight in the development of the topography in the Late Glacial and Holocene (Raukas \& Vaher, 1981; Мийдел \& Пуура, 1982; Raukas et al., 1988).

\section{ACKNOWLEDGEMENTS}

The author expresses his thanks to his colleague Kalev Orgla, who made the necessary mathematical calculations. Valuable comments were made by Väino Puura and Anto Raukas. Helle Kukk corrected the English language. The figures were drawn by Kaie Ronk and the text was typed by Urve Pohl. My sincere thanks to all these persons.

This work was partly supported by grant LCA000 of the International Science Foundation. 


\section{REFERENCES}

Gray, J. M. 1974. Lateglacial and postglacial shorelines in Western Scotland. - Boreas, $3,4,129-138$.

Gray, J. M. 1978. Low-level shore platforms in the south-west Scottish Highlands: Altitude, age and correlation. - Trans. Inst. Brit. Geogr., New Ser., 3, 151-164.

Heikkinen, O. 1975. A trend-surface analysis of relief in Sipoo, southern Finland. Fennia, 141, 1-47.

Heikkinen, O. and Kurimo, H. 1977. The postglacial history of Kitkajärvi, North-Eastern Finland, as indicated by trend-surface analysis and radio-carbon dating. Fennia, 153, 1-32.

Loken, O. H. 1962. The lateglacial and postglacial emergence and the deglaciation of northernmost Labrador. - Geogr. Bull., 17, 23-56.

Lundquist, J. 1965. The Quaternary of Sweden. - In: Rankama, K. (ed.). The Geologic Systems. The Quaternary. Vol. 1. John Wiley \& Sons, London, 139-198.

Mörner, N.-A. 1969. The Late Quaternary history of the Kattegatt Sea and the Swedish West Coast. Deglaciation, shore displacement, chronology, isostasy and eustasy. Sver. Geol. Unders. Ser. C 640.

Ramsay, W. 1929. Niveauverschiebungen, eisgestaute Seen und Recession des Inlandeises in Estland. - Fennia, 52, 2.

Raukas, A., Vaher, R. 1981. Tektoonika osast Eesti aluspõhja reljeefi ja nüüdispinnamoe kujundamisel. - In: Settekivimid ja tektoonika. Tallinn, 6-22.

Raukas, A., Tavast, E. and Vaher, R. 1988. Some structural and geomorphological aspects of recent crustal movements in Estonia. - J. Geodyn., 10, 295-300.

Saarnisto, M., Huhn, F. 1972. Trend surface analysis of a raised shoreline of Lake Saimaa, Finland. - Soc. Sci. Fennica. Comment. Phys.-Math., 42.

Sildvee, H. 1991. Eesti maavärinad ei jää kahe silma vahele. - Eesti Loodus, 12, 699701.

Svendsen, J. I. and Mangerud, J. 1987. Late Weichselian and Holocene sea-level history for a cross-section of western Norway. - J. Quat. Sci., 2, 113-132.

Zhelnin, G. 1966. On the recent movements of the Earth's surface in the Estonian S.S.R. - Ann. Acad. Sci. Fennicae. Ser. A. III. Geol.-Geogr., 90, 489-493.

Vallner, L., Sildvee, H. and Torim, A. 1988. Recent crustal movements in Estonia. J. Geodyn., 9, 215-233.

Вахер Р. М. 1983. Тектоника фосфоритно-сланцевого бассейна Северо-Восточной Эстонии. Автореф. канд. дис. Минск.

Карукяпп Р., Таваст Э. 1985. Структура и ледниковый морфогенез Пандивереской возвышенности. - Изв. АН ЭССР. Геол., 34, 1, 22-29.

Кессел Х., Мийдел А. 1973, О поздне- и послеледниковых движениях земной коры на территории Эстонии. - Изв. АН ЭССР. Хим. Геол., 22, 3, 257264.

Кессел Х., Раукас А. 1984. О геологической корреляцин древнебереговых образований Балтийского моря в Эстонии и Швеции. - Изв. АН ЭССР. Геол., 33, $3 / 4,146-157$.

Кошечкин Б. И. 1984. Динамика плейстоценового оледенения и природа трансгрессий морских бассейнов на севере Европы. - Изв. Всес. геогр. об-ва, 116, вып. 4, $323-328$.

Мийдел А. 1966. О связи между современными движениями земной коры и эрозионно-аккумулятивной деятельностью рек Эстонии. - Изв. АН ЭССР. Сер. физ.-матем. и техн. наук, $15,1,121-133$.

Мийдел А. М., Пуура В. А. 1982. Проблемы неотектоники северо-запада ВосточноЕвропейской платформы (геологические аспекты). - In: Неотектоника и современная динамика литосферы. Тез. докл. Ч. І. Таллинн, 140-143.

Орвику К. К. 1960. О неотектонических движениях в Эстонской ССР на основе геологических данных. - Мат-лы совещ. по вопросам неотектонических движений в Прибалтике. Тарту, 120-143.

Орвику К. К. 1969. Влияние поднятия земной коры на геолого-геоморфологическое 
развитие территории Эстонии в позднеледниковое время в голоцене. - In: Новейшие движения, вулканизм и землетрясения материков и дна океанов. Наука, Москва, 163-171.

Оргла К. 1991. Графнческое представление регрессионных полиномов на графопостроителе ЭС ЭВМ для анализа геологических данных. - In: Применение ЭВМ при решении задач геологии полезных ископаемых Эстонии. Таллинн, $3-30$.

Побул Э. А., Сильдвээ Х. Х. 1975. О блоковом строении кристаллического фундамента Эстонин. - In: Современные движения территории Прибалтики. Тарту, $64-73$.

Пярна К. Т. 1962. О геологии Балтин̆ского приледникового озера и крупных местных приледнйковых озер на территории Эстонии. Автореф. канд. дис. Таллинн.

Ряхни Э. Э. 1973. О блоковых неотектонических движениях на территории Эстонии. - Изв. АН ЭССР. Хим. Геол., 22, 4, 81-94.

Тийтс Т., Вийкманн Э., Каролин М., Пукк К. 1986. СТАТЕС-2. Средства управления и руководство по применению. Таллинн.

Туулинг И. И. 1990. Структура Прибалтийского бассейна горючих сланцев и фосфоритов. Автореф. канд. дис. Минск.

Уттер Л. Р. 1964. Попытка геологической интерпретации схемы изобаз территории Эстонской ССР. - In: Современные и новейшие движения земной коры в Прибалтике. Вильнюс, 94-100.

Хейнсалу Ю., Сильдвээ Х. 1971. О связях между неотектоническими и современными дифференцированными движениями и зонами разломов в СевероВосточной Эстонии. - Изв. АН ЭССР. Хим. Геол., 20, 3, 260-265.

Шляупа А. И., Берзинь Л. Э., Каяк К. Ф., Страуме Я. А. 1982. Неотектоническая карта республик Советской Прибалтики. Масштаб 1:500 000. Объяснительная записка, Вильнюс,

\title{
TRENDANALUUSI KASUTAMISE TULEMUSI LÄÄNEMERE RANNAMOODUSTISTE UURIMISEL EESTIS
}

\author{
Avo MIIDEL
}

Trendanalüüsiga uuriti Balti paisjärve, Antsülusjärve ja Litoriinamere transgressioonide ajal kujunenud rannamoodustisi selgitamaks võimalikke ebakorrapärasusi hilis- ja pärastjääajal toimunud maapinna kerkimises.

Esimese astme trendi pinnad viitavad korrapärasele maatõusule, mis territoriaalselt väheneb loodest kagusse ja ajaliselt jäätumise lõpust tänapäevani. Teise ja eriti kolmanda astme pinnad on kõverdunud. See võib olla põhjustatud pigem Fennoskandia kerkimisest kui lokaalsete struktuuride ja murrangute liikumisest Eestis.

On juhitud tähelepanu kireima kerkimise suuna mutumisele Pleistotseeni lõpul ja Holotseenis. See võib olla seotud Fennoskandia kerketsentri nihkumisega. Uhtlasi viitab see glatsioisostaatilise faktori tähtsuse vähenemisele Holotseenis toimunud summaarses kerkimises.

Valdavalt kahe meetrini ulatuvate jääkide põhjal oletatud lokaalsete struktuuride võrdlemine geoloogilise andmestikuga ei tõestanud selliste struktuuride reaalsust. Seega ei õnnestunud tõestada ka aluspõhja plokkide mobiilsust. Võimalik, et Lääne-Eestis ja saartel hakkas alates Litoriinamere perioodist ilmnema suhtelișe vajumise tendents. 


\title{
НЕКОТОРЫЕ РЕЗУЛЬТАТЫ ИЗУЧЕНИЯ БЕРЕГОВЫХ ОБРАЗОВАНИЙ БАЛТИЙКОГО МОРЯ С ПРИМЕНЕНИЕМ ТРЕНД-АНАЛИЗА
}

\author{
Аво МИИДЕЛ
}

C помощью тренд-анализа исследованы транегрессивные образования Балтийского ледникового озера, Анцилового озера и Литоринового моря с целью установить возможные нерегулярности в поднятии земной поверхности в поздне- и послеледниковое время.

Поверхности тренда первой степени указывают на регулярное поднятие, по площади уменьшающееся с северо-запада ңңа юго-восток, а по времени - от конца оледенения до наших дне́й. Поверхности тренда второй и, особенно, третьей степеней искривляются, что обусловлено скорее поднятием Фенноскандии, чем движениями локальных структур и разломов в Эстонии.

Обращено внимание на изменение азимута максимального поднятия в конце плейстоцена и в голоцене, что может быть связано с перемещением центра поднятия Фенноскандии либо, что не исключено, с уменьшением роли гляциоизостатического фактора в суммарном поднятин.

Сравнение результатов, полученных на основе остаточных отклонений локальных структур, с геологическими данными не подтверждает реальности этих структур. Таким образом, не удалось доказать и мобильности блоков, установленных в кристаллическом фундаменте и осадочном чехле.

Возможно, что проявляется тенденция к относительному опусканию Западной Эстонии и островов Западно-Эстонского архипелага начиная со времени Литоринового моря. 